\title{
Application of life cycle thinking towards sustainable cities: a review
}

Anna Petit-Boix ${ }^{a}$, Pere Llorach-Massana ${ }^{a, b}$, David Sanjuan-Delmás ${ }^{a}$, Jorge Sierra-Pérez ${ }^{\mathrm{a}, \mathrm{c}}$, Elisabet Vinyes $^{\mathrm{a}}$, Xavier Gabarrell ${ }^{\mathrm{a}, \mathrm{d}}$, Joan Rieradevall ${ }^{\mathrm{a}, \mathrm{d}}$, Esther Sanyé-Mengual*a,e

a Sostenipra (ICTA-IRTA-Inèdit; 2014 SGR 1412) Institute of Environmental Science and Technology (ICTA; Unidad de excelencia «María de Maeztu» (MDM-2015-0552)), Universitat Autònoma de Barcelona (UAB), Edifici ICTA-ICP, Carrer de les Columnes, 08193 Bellaterra, Barcelona, Spain.

bELISAVA Barcelona School of Design and Engineering, La Rambla 30-32, 08002 Barcelona, Spain

${ }^{c}$ Centro Universitario de la Defensa. Ctra. de Huesca s/n, 50090, Zaragoza, Spain

${ }^{\mathrm{d}}$ Department of Chemical, Biological and Environmental Engineering, Xarxa de Referència en Biotecnologia (XRB), School of Engineering (ETSE), Universitat Autònoma de Barcelona (UAB), Campus of the UAB, Bellaterra (Cerdanyola del Vallès), 08193 Barcelona, Catalonia, Spain.

${ }^{\mathrm{e}}$ Research Center in Urban Environment for Agriculture and Biodiversity (RESCUE-AB), Università di Bologna (UNIBO), Bologna, Italy

*Corresponding author at esther.sanye@unibo.it

\begin{abstract}
Defining sustainable cities is not straightforward. The main issues involved in urban sustainability are buildings, energy, food, green areas and landscape, mobility, urban planning, water and waste; and their improvement is promoted through different strategies. However, a quantitative method, such as life cycle thinking (LCT), is essential to evaluating these strategies. This paper reviews LCT studies related to urban issues to identify the main research gaps in the evaluation of these improvement strategies. The review identifies the main sustainability strategies associated with each urban issue and compiles articles that deal with these strategies through LCT, including environmental life cycle assessment (LCA), life cycle costing (LCC), social LCA (S-LCA) and life cycle sustainability assessment (LCSA), as well as integrated analyses with combined tools. Water, waste and buildings are the urban issues that accounted for a larger amount of studies. In contrast, a limited number of papers assessed urban planning and energy (excluding energy in buildings). Strong interrelations among urban issues were identified, most of them including water. In terms of methods, $79 \%$ of the studies exclusively applied life cycle tools (i.e., LCA, LCC, S-LCA or LCSA). Within this group, the environmental dimension was the focus of $84 \%$ of the papers. Single environmental indicators (e.g., global warming) were common in $20 \%$ of the analyses, highlighting the need to integrate more impact categories to prevent trade-offs. In the field of social and sustainability assessment, there is a need for methodological advances that foster their application in urban areas. Further research should cover the thematic and methodological gaps identified in this paper, such as developing models that assess complex urban issues, generating comprehensive LCT studies and promoting multi-indicators. Life cycle tools might benefit from revising the methodology with stakeholders to optimize the understanding and communication of life cycle results for policy- and decision-making processes.
\end{abstract}

Keywords: sustainability, life cycle assessment, urban metabolism, sustainable policy, life cycle thinking

\section{Introduction}

Sustainability is key to ensuring good living standards in cities without compromising the environment, economy and society, especially considering that already $50 \%$ of the world's population lives in urban areas (UN, 2012). Cities are the result of combining technical, cultural, institutional, economic and psychological 
systems (Allenby, 2009) and their integrated management is complex. In terms of environmental performance, it is widely recognized that cities are the source of a number of environmental impacts, such as climate change (Kennedy et al., 2012), contributing to $70 \%$ of the global greenhouse gas emissions (GHG) (UN-HABITAT, 2011). However, there are other sectors outside the city boundaries, such as agriculture or power generation, that are linked to the growth of cities and also contribute to the global environmental performance of citizens (Satterthwaite, 2008). Additionally, urban sustainability also faces social justice issues (Harvey, 2009) while promoting the development of local economies. The question is: what is a sustainable city and which are the strategies that foster sustainable cities?

There are many issues involved in the daily metabolism of a city, e.g., food, energy, water, transportation, etc. In this paper, we identify the issues included in urban management, which are thus essential to defining future sustainable cities. Within these issues, we study the strategies promoted by reference institutions for improving their performance. In the framework of life cycle thinking (LCT), we discuss how these strategies were covered in the literature to determine their implementation potential at an urban scale.

\subsection{Defining a sustainable city}

A consensual definition of sustainable cities does not exist, although most organizations share the same viewpoint. The Institute for Sustainable Communities (2017) published a concise proposal based on the Sustainable Communities Task Force Report (President's Council on Sustainable Development, 1998): “ $A$ sustainable community is one that is economically, environmentally, and socially healthy and resilient. It meets challenges through integrated solutions rather than through fragmented approaches that meet one of those goals at the expense of the others". This definition calls for an integration of the policies and strategies aimed at improving the sustainability of key urban issues. However, these are typically dealt with independently to solve specific problems, such as the access to public transport or waste management. To identify the strategies proposed for each urban issue in the development of sustainable cities, we screened a set of fifteen reports and data from international organizations. Subsequently, we identified 28 potential improvement strategies (Table 1) that refer to 8 urban issues, namely buildings, energy, food, green spaces and landscape, mobility, urban planning, waste and water. In general, most strategies point to an increased process efficiency, the implementation of greener materials/designs and the integration of new technologies into the existing pool of alternatives.

<Table 1>

\subsection{Life cycle thinking (LCT) applied at the city scale}

The feasibility of each strategy in environmental, economic and social terms is key to ensuring a sustainable urban performance. Quantitative studies can help to conduct this assessment, and LCT might be a suitable tool. According to the UNEP/SETAC Life Cycle Initiative (2017) LCT is "about going beyond the traditional focus on production site and manufacturing processes to include environmental, social and economic impacts of a product over its entire life cycle". This approach can be applied at different scales that range from single products to more complex systems, such as cities. Within this framework, four methods were developed to quantify the dimensions of sustainability. Life cycle 
assessment (LCA) (ISO 14040:2006) and life cycle costing (LCC) (ISO 15686-5:2008) quantify the environmental and economic impacts of a product system from raw material procurement to end of life, respectively. Social LCA (S-LCA) and life cycle sustainability assessment (LSCA) are newer methods (UNEP-SETAC, 2011, 2009), but their application is still incipient and needs standardization. LCT is the core of several policy action plans, including ecolabels and eco-innovation strategies (European Commission, 2010a). Indeed, as stated in previous literature the development of a comprehensive methodology for the implementation of LCSA is still lacking, and issues regarding indicators, weighting and trade-offs between validity and applicability must be addressed (Finkbeiner et al., 2010; Guinée et al., 2011). S-LCA needs further development, facing major challenges with regard to representation of results and data quality, among others (Macombe et al., 2013).

As defined in Section 1.1, strategies implemented to achieve sustainable cities should not work against each other. In this sense, LCT can provide integrated results for decision-making. However, LCT has been applied differently to the various issues involved in urban metabolism, leading to unbalanced data availability for evaluating sustainable strategies. Although the methodological limitations of LCT are well-known among practitioners, there is a need to identify the shortcomings of the LCT application to sustainability aspects related to cities, including both the topic coverage and methodological advancements.

\subsection{Goal of the review}

The goal of this review is to evaluate to what extent LCT research has assessed sustainable cities by considering the issues addressed in urban sustainability strategies. The specific objectives of this study are (i) to review how the strategies related to buildings, energy, food, green spaces and landscape, mobility, urban planning, waste and water were assessed from a life cycle perspective, and (ii) to identify the research gaps and methodological shortcomings related to each issue. This contribution also outlines the research needs that will support the development of urban sustainability policies from an LCT perspective.

\section{Methods}

We conducted a systematic review of scientific literature. We gathered articles on each urban issue and strategy from March 2015 to July 2016 through online catalogues (i.e., ISI Web of Science, Google Scholar and Scopus) and cross-citation. We searched common keywords related to urban sustainability and LCT (e.g., sustainable cities, social LCA, carbon footprint) and specific keywords for each of the topics under assessment (e.g., urban agriculture, green spaces, waste management) (see Table 1).

The review includes 151 peer-reviewed scientific papers published in indexed journals (Table 2). The papers were classified based on the 8 urban issues and 28 strategies identified in Table 1. In the specific case of buildings, we found many papers dealing with materials, constructive solutions, construction processes, and maintenance of the indoor comfort. 24 papers were selected to represent the on-going research on this issue based on journal impact factor, number of citations, completeness and relationship with the sustainability strategies. Once the papers were classified, a set of aspects were screened, namely study area, scope, sustainability dimension (i.e., LCA, LCC, S-LCA, LCSA), type of study (e.g., life cycle 
tools, integrated schemes), indicators employed and main results (see the Supporting Information). The analysis provided an overview of sustainability assessments at different levels, i.e., strategies, urban issues and city. Furthermore, we paid attention to the methodological approach based on LCT tools.

However, city boundaries are difficult to define. In this study, we considered phenomena taking place within urban areas for each urban issue, as well as peri-urban processes mainly related to food. Background system boundaries involve those upstream and downstream systems exclusively related to the urban metabolism (i.e., energy, water, resources, emissions and waste) (Figure 1). In other words: the studies that we considered refer to processes that occur within urban areas, but they have intrinsic inputs and outputs that come from the outside. For instance, we included energy efficiency strategies that are implemented in cities, but this energy comes from power plants located in other areas. However, energy production strategies that occur beyond the city boundaries are excluded.

\section{$<$ Table 2>}

$<$ Figure 1>

\section{LCT research on urban sustainability}

This section presents the results of the review and discusses the state of the art for the following issues: buildings, energy, food, green spaces and landscape, mobility, urban planning, waste and water.

\subsection{Buildings}

Specific strategies were proposed for improving the building sector and its contribution to urban sustainability. The four main strategies focus on reducing the energy (B1, B2) and resource consumption (B3, B4) during the life cycle of buildings and related emissions (Table 1). A detailed literature review is available in the Supporting Information 1.1.

The most evaluated strategy is the efficient use of energy, water and other resources in buildings (B1). Based on the nearly zero-energy building (NZEB) concept, LCA methodologies, and more specifically the life cycle energy assessment (LCEA), were used to quantify the energy consumption in buildings during the operation phase and its related environmental impacts (Blom et al., 2011, 2010a; Johnson, 2011; Scheuer et al., 2003). This life cycle quantification was addressed using diverse approaches, e.g., assessing the optimal insulation conditions, the management of heating and cooling systems or the influence of human behavior (Blom et al., 2011; Çomaklı and Yüksel, 2003; de Meester et al., 2013). These studies noted the importance of integrating the energy design of buildings for adapting to the user's lifestyle and optimizing the energy demand. Additionally, LCA and LCCs evaluated the benefits of building materials and maintenance activities in terms of improving energy efficiency (Ardente et al., 2008; Blom et al., 2010b; de Gracia et al., 2010; Syrrakou et al., 2006)

The Net-ZEB concept is an extension of the NZEB, which implies that buildings cover their energy demand using onsite renewable energy sources (strategy B2). This generated a growing number of studies that integrate renewable energy into the total LCEA of buildings. LCEA and LCC are often used to analyze the 
effects of installing such systems. Results vary depending on the climatic conditions, the materials included in the energy equipment and the high cost of producing this equipment (Agrawal and Tiwari, 2010; Dodoo and Gustavsson, 2013; Elkinton et al., 2009; Koroneos and Tsarouhis, 2012).

After optimizing the operation phase, using more sustainable construction materials is essential (B3). Many studies focused on the embodied energy of building materials, constructive systems and buildings using LCA (Monahan and Powell, 2011; Sierra-Pérez et al., 2016b; Thormark, 2002; Zabalza Bribián et al., 2011). However, renewable insulation materials still need to undergo sufficient development to be comprehensively implemented in the building sector. Renewable materials such as kenaf fibers, cotton, jute, flax, hemp and cork were included in environmental studies (Sierra-Pérez et al., 2016a), but more environmental and economic data on manufacturing is needed.

To increase the durability of buildings (B4) different alternatives were studied. Refurbishing buildings might improve their energy efficiency and increase their lifespan. Often, these improvements consist of increasing thermal insulation (Assiego de Larriva et al., 2014; Nicolae and George-Vlad, 2015). Further, this strategy was partly applied by incorporating deconstruction materials into buildings (Blengini, 2009; Densley Tingley and Davison, 2012), which increases the durability of building materials and facilitates future reuse.

So far, LCA has been widely applied in the building sector from an environmental perspective; in contrast, economic assessments are limited. Some specific studies addressed social aspects in buildings (Hosseinijou et al., 2013; Onat et al., 2014), but more efforts are needed to understand the social dimension and the effects of buildings on users, who play a key role in the implementation of energy efficiency strategies. Furthermore, most of the studies included a complete set of environmental indicators, while some others focused on the energy performance, such as Berggren et al. (2013). Finally, there is also a need for internationally agreed data and methodologies (Menzies et al., 2007) for conducting these analyses at different scales.

\subsection{Energy}

Energy issues aim to reduce urban energy consumption and its related impacts. Four strategies were identified (Table 1) that mainly focus on the production and consumption of renewable energy (E1, E2) and the promotion of energy efficiency in services and residential areas (E3, E4). A detailed literature review is available in the Supporting Information 1.2.

The transition towards renewable energy (E1) was repeatedly reported in sustainability planning. Although renewable energy was widely assessed from a life cycle perspective, only a few studies focus on urban energy systems. The generation of domestic hot water was studied, concluding that geothermal energy generates lower environmental burdens than solar thermal (Chiavetta et al., 2011). Another system are micro-wind turbines for electricity generation, whose environmental burdens depend on the geographical location and material composition (Allen et al., 2008). Vandevyvere and Stremke (2012) presented practical design principles for integrating renewable energy into the built environment. These studies lead to implementing self-supplied energy resources in cities (E2). In the framework of urban parks, Oliver-Sola 
et al. (2007) assessed global self-sufficiency by considering factors such as the potential production of renewable energy. Both approaches contribute to increasing energy efficiency in cities (E3). At the urban level, Tähkämö et al. (2012) studied two types of street lighting using LCC (e.g., high-pressure mercury (HPM) and LED). Whereas HPM costs depend on the operation phase, the installation phase is more relevant in LED technology. The best option will therefore depend on the cost of energy in a specific urban area.

The assessment of energy issues relates to other urban issues, such as buildings (B), mobility (M) and urban planning (UP). In this section, only those studies associated with energy planning and production at the district and urban scales were included. Accordingly, more studies are needed to evaluate the performance of renewable energy towards urban self-sufficiency from a sustainability standpoint, particularly considering the economic and social dimensions. The latter would be beneficial to address the access to energy in different types of cities and social strata. Although Ristimäki et al. (2013) applied "LCC affordability", the income of citizens was not addressed to evaluate the access to energy (E4). Regarding specific methodological aspects, some studies limited the assessment to the global warming (GW), although such practice can lead to trade-offs among impact categories, as energy has a large influence on the GW.

\subsection{Food}

Food issues were addressed in urban policy for ensuring food security and quality to citizens. Literature covered two strategies towards urban sustainability, i.e., building up urban agriculture (F1) and promoting regional and local food products (F2) (Table 1), as compiled in Supporting Information 1.3.

Urban agriculture was recently approached through life cycle tools and few articles are available. Although studies initiated in 2010, life cycle data was not experimental until recently. Some authors evaluated the potential environmental benefits of urban agriculture at the city scale (Astee and Kishnani, 2010; Kulak et al., 2013; Sanyé-Mengual et al., 2015a). To do so, they accounted for the environmental savings resulting from local food production, which replaces the consumption of conventional food and, thus, avoids the environmental burdens associated with their supply-chain. Only a few types of urban agriculture forms were assessed in the literature, e.g., urban gardens (Kulak et al., 2013), rooftop greenhouses (SanyéMengual et al., 2015b) and rooftop community gardens (Sanyé-Mengual et al., 2015c). However, Kulak et al. (2013) employed literature data on conventional agriculture as a proxy for evaluating urban agriculture. Sanyé-Mengual et al. (2015b, 2015c) combined LCA and LCC to observe the environmental and economic performance of rooftop agriculture. The social dimension of urban agriculture is yet to be considered in life cycle studies. In general, papers highlighted the benefits of urban agriculture as local production initiatives and demonstrated the potential environmental and economic savings from a consumer perspective.

Although research on local production does not exclusively refer to cities, urban areas are the main food consumers. Several LCA studies assessed local supply-chains by accounting for the environmental burdens of local and imported products. Most studies considered local production in Europe (e.g., UK) (Jones, 2002), with apple being the main product of interest. Although local production is commonly associated with lower environmental impacts, results depend on the geographical area, cultivation technique and production stage (Edwards-Jones et al., 2008). Morgan (2009) emphasized the need for using LCA in the 
evaluation of local food to include all the life cycle stages. The economic and social burdens of local production were not evaluated in life cycle studies.

Regarding the methodological approach to urban food, some limitations exist. Studies on urban agriculture mostly focused on the environmental dimension. In particular, attention was paid to the environmental savings of local production by calculating the avoided burdens of replacing conventional food with local food (e.g., Astee and Kishnani 2010). Further environmental, economic and social benefits should be considered in comprehensive life cycle studies. Additionally, some of the existing articles are based on literature (e.g., Kulak et al. 2013) rather than experimental data from real urban crops. Furthermore, studies must represent the plurality of urban agriculture forms, cultivation techniques and vegetables. In terms of geographical representation, most of the papers assessed European case studies, unveiling the need to consider other regional areas for increasing the global knowledge. For both F1 and F2 strategies, studies focused on two indicators, i.e., GW and energy consumption, due to the importance of transportation in these environmental impacts. However, Payen et al. (2015) demonstrated that trade-offs can be produced among indicators and, thus, it is recommended to include a set of indicators rather than a single one. Finally, the economic and social dimensions of sustainability are commonly avoided in life cycle studies of urban food production.

\subsection{Green spaces and landscape}

Green spaces and landscape are essential in cities to guaranteeing the access to natural and leisure areas. Literature addressed two strategies that aimed to increase urban green areas (G1) and foster green buildings (e.g., green roofs, green façades, and living walls) (G2) (Table 1). A detailed review is provided in Supporting Information 1.4.

Two analyses evaluated the life cycle performance of green areas in cities (G1). Strohbach et al. (2012) accounted for the carbon footprint of an existing green space project and determined that the benefits of carbon sequestration might be notable, especially when reducing the maintenance intensity and tree mortality. From another perspective, Oliver-Sola et al. (2007) highlighted the environmental impacts resulting from services provided in urban parks (e.g., museums, sports centers, or recreational areas). In the field of urban green areas, many studies focused on the carbon storage and impact offsetting related to trees, forests and natural green areas (Baró et al., 2014; Hutyra et al., 2011; Jo, 2002; Nowak, 1994; Zhao et al., 2010). However, integrating these results into the global environmental performance of green areas is needed to identify the balance between the life cycle impacts and benefits.

Regarding the implementation of green elements in buildings, studies assessed green roofs and green walls (G2). In particular, green roofs have multiple functions in cities and, thus, they can also be evaluated as insulation systems or water management strategies. In this sense, authors mostly considered collateral effects in their life cycle studies, particularly carbon sequestration (Cerón-Palma et al., 2013) and improved thermal insulation (Kosareo and Ries, 2007; Saiz et al., 2006). From an economic standpoint, the monetization of these benefits highlighted the potential of green roofs compared to conventional façades and roofs (Porsche and Köhler, 2003). Regarding the design, using recycled materials might reduce the environmental footprint of green roofs (Bianchini and Hewage, 2012) and the maintenance of the system 
was a key contributor to the economic and environmental costs (Peri et al., 2012a, 2012b; Wong et al., 2003).

However, most of the studies did not include a comprehensive life cycle approach that considers all of the stages (Porsche and Köhler, 2003; Saiz et al., 2006). Peri et al. (2012a; 2012b) covered this methodological gap by conducting complete life cycle analyses of green roofs. Nonetheless, as green areas are multifunctional systems, studies should consider a complete set of impacts and benefits to estimate their real contribution to urban sustainability. Regarding the social dimension, Peri et al. (2010) unveiled the need to address the social impacts of green roofs and proposed a S-LCA framework, although it only discusses potential indicators related to stakeholder evaluation. In terms of indicators, most papers account for various impact categories. Evaluating a single environmental benefit of green roofs (e.g., carbon sequestration in Cerón-Palma et al. (2013)) might underestimate their role in the design of sustainable cities.

\subsection{Mobility}

Mobility challenges arise from horizontal urban growth. In this sense, five strategies (Table 1) covered collective and alternative means of transportation (M1), fuel efficiency (M2, M3), freight transportation (M4) and Intelligent Transport Systems (ITS) (M5). A detailed literature review is available in the Supporting Information 1.5.

Some authors assessed the reduction of private car usage by promoting alternative ways of transportation (e.g., bicycle, public transport, walking) (M1). From a life cycle perspective, Cherry et al. (2009) and Nahlik and Chester (2014) reported positive environmental consequences resulting from the use of bicycles and/or public transportation when replacing private cars. A complete sustainability assessment was provided by Kennedy (2002) for comparing public and private options, where public transportation scored better in the environmental dimension, but needed improvement in social and economic terms. However, this study did not consider the life cycle approach.

The efficiency of private vehicles was covered in strategy M2, which consists of promoting the purchase of efficient cars or applying higher taxes to high-polluting vehicles. In this sense, different types of technologies were assessed using LCA, such as electric and hydrogen vehicles (Lucas et al., 2013) and propulsion technologies (e.g. conventional fuel engines, low sulfur diesel engines, compressed natural gas, or electric vehicles) (Lave et al., 2000). Further, Mendoza et al. (2016) studied the environmental performance of public charging facilities, which might be combined with solar panels for better results (Mendoza et al., 2015). Public transportation is also involved in the use of greener vehicles (M3). Different types of fuels were assessed in buses (e.g., diesel, natural gas, or hybrid options) (Ally and Pryor, 2008). In this case, the authors could not identify the best solution given tradeoffs among the impact indicators considered. However, as detected in other disciplines, an LCA of this type of strategy might identify the potential decentralization of pollution, meaning that cities might import or export environmental impacts through commuters.

The logistics sector is also involved in urban mobility. Regarding heavy trucks, the creation of a new distribution system that concentrates the delivery of commodities in the outskirts of towns is related to 
strategy M4. To the authors' knowledge, no studies dealt with this option so far, but they might be necessary for determining the balance between the investment in infrastructure and fleet and its environmental benefits. Strategy M5 referred to the use of ITS, which provide information to drivers about the best routes, for instance. ITS have a great potential to reduce $\mathrm{CO}_{2}$ emissions resulting from private transportation according to Pagoni et al. (2012). Nevertheless, this study focused on ITS benefits in roads and not in cities, and further research is needed. Additionally, future studies should determine the potential benefits and social acceptance of using ITS technologies in cities.

In the field of urban mobility, studies need to validate the sustainability of each strategy quantitatively. A life cycle approach might be useful to track the processes involved in the transportation sector. In addition, the elaboration of eco-efficiency (e.g., LCA+LCC) indicators may be interesting to determine the relationship between the money invested by public administration and the resulting environmental benefits. Existing studies already coupled some economic and environmental indicators (Lave et al., 2000), but the environmental dimension should include a wider set of indicators, such as in Mendoza et al. (2015). Finally, S-LCA studies are lacking and they are needed to estimate the impacts of transportation on the society. Furthermore, future studies may include the influence of social participation on the overall acceptance and application of these strategies.

\subsection{Urban planning}

In terms of sustainable urban planning, strategies promoted the integration of land use and transportation (UP1), compact urban models (UP2), regional planning (UP3) and sustainable urbanism (UP4) (Table 1), as compiled in the Supporting Information 1.6.

The integration of land use and transportation in decision-making was a priority (UP1). The environmental impacts of transportation were evaluated by Li and Wang (2009), where the metabolism of Beijing (China) was analyzed through hybrid emergy-LCA, concluding that mitigation measures should focus on buildings. Other studies assessed the influence of urban density on the environmental impacts of cities (UP2). Using environmental input-output (EIO)-LCA, Norman et al. (2006) found that low density areas were 2 to 2.5 times more energy intensive than compact areas. However, no clear connection was found between environmental impacts and densities in Finland (Heinonen and Junnila, 2011). Further analyses should provide more data about the effects of transportation and urban sprawl on the environmental impacts of cities, which might be useful for identifying key policies and programs. Similarly, specific aspects of sprawl and compact versus fragmented cities should be assessed.

Studies on the promotion of regional planning (UP3) are scarce. A framework for applying LCA in land planning and its bottlenecks were identified by Loiseau et al. (2013), who proposed a set of indicators to be used in France. Thus, identifying and quantifying the environmental benefits of regional planning from a life cycle perspective is a field to explore. Finally, sustainable urban planning (UP4) generally overlaps with the other strategies. Different parameters were considered in this type of assessment, e.g., building age (Balocco et al., 2004) or structural solutions (Oliver-Solà et al., 2009). 
Although the studies reviewed consider urban planning in their methodological framework, this issue still calls for further assessments from a life cycle standpoint. In addition, to the authors' knowledge no studies considered the economic and social impacts of urban planning. Furthermore, the indicators implemented in these analyses are limited. Most of them referred to GW through novel methodologies, such as hybrid emergy-LCA, EIO-LCA, exergy and GW-charts.

\subsection{Waste}

Sustainable waste management (WM) might ensure livability and minimize health impacts in urban areas. LCA studies have evaluated two strategies. i.e., to improve collection and waste management (WM) systems (W1) and to promote waste prevention (W2) (Table 1). A detailed review is provided in Supporting Information 1.7 .

Regarding waste collection and management (W1), multiple studies compare the environmental impacts of different technologies. Treatment processes (e.g., incineration) have a larger contribution to the environmental impacts than collection and transportation (Song et al., 2013). To increase the efficiency of waste collection, authors highlighted the relevance of collection routes, location of management facilities and transport efficiency (Iriarte et al., 2009; Merrild et al., 2012; Rosenbaum et al., 2008; Zamorano et al., 2009). An increased WM efficiency and the integration of energy recovery processes were the most environmentally friendly options. Integrated WM showed the highest environmental and economic benefits (Buttol et al., 2007; Herva et al., 2014; Song et al., 2013; Thomas and McDougall, 2005). Recycling displayed environmental benefits when replacing primary materials (Feo and Malvano, 2009; Koroneos and Tsarouhis, 2012; Muñoz et al., 2010) and when compared to incineration (Iriarte et al., 2009; Merrild et al., 2012). Incineration was the most preferable disposal option in environmental terms (Morselli et al., 2008) due to energy recovery (Buttol et al., 2007). GHG accounting in WM strongly depended on the efficiency of landfill gas collection, electricity generation and biogenic carbon modeling (Vergara et al., 2011).

Sevigné Itoiz et al. (2013) set a methodology to calculate the contribution of WM to GW at the national scale and showed figures for Spain. This study was framed in the ZEROWASTE project (http://www.medzerowaste.eu/) which also quantified the burdens for Italy, Greece and Slovenia. Due to the role of waste flows in a circular economy, Sevigné-Itoiz et al. $(2014,2015)$ proposed an integrated material flow analysis (MFA) and LCA to evaluate recycling processes from a consequential perspective that includes market data. Such scheme broadened the scope of sustainable WM to the global market, which is essential to supporting WM decisions at both strategic and operating levels (Arena et al., 2003).

Some authors highlighted the positive environmental benefits of waste prevention (W2) (Vergara et al., 2011), even at the municipal level (Cleary, 2014). In particular, food waste prevention showed a large potential in reducing the environmental footprint of waste management (Gentil et al., 2011) due to the resources tied to the life cycle of food (e.g., packaging) (Nessi et al. 2012, 2015). However, the benefits of waste prevention strategies clearly depend on the context (e.g., WM scenarios) and LCI modeling (e.g., recycling vs virgin material) (Gentil et al., 2011; Slagstad and Brattebø, 2012). Furthermore, when waste 
prevention strategies produce economic savings, re-bound effects can result in new consumption patterns with different environmental impacts (Martinez-Sanchez et al., 2016).

Notwithstanding the relevance of WM in health, little attention was paid to social issues from a life cycle perspective. To the authors' knowledge, the only LCSA study of this review was applied to the recycling of used cooking oils (Vinyes et al., 2012). Using an economic framework, Martinez-Sanchez et al. (2016) applied a complete LCC to food waste management thereby assessing the economic (LCC), environmental (ELCC) and social (SLCC) dimensions. As in other issues, some authors limited the assessment to the GW category.

\subsection{Water}

Water issues were broadly analyzed to provide water access and security to urban population. Sustainable strategies on water services aim to improve water and sewer networks (Wa1), implement retrofit systems (Wa2), enhance urban water retention (Wa3) and promote alternative water flows (Wa4, Wa5) (Table 1). This life cycle literature is detailed in Supplementary Material 1.8.

To date, several studies have identified the environmental and economic impacts of potable and wastewater treatment plants, e.g., Racoviceanu et al. (2007) or Corominas et al. (2013), given their importance in supporting water supply and sanitation. Some studies focused on the implementation of resource and energy efficient networks in urban areas (Wa1). Most of them assessed constructive designs (Petit-Boix et al., 2014; Sanjuan-Delmás et al., 2014; Venkatesh et al., 2009), but there is a lack of LCA and LCC studies that integrate structural and local aspects. The configuration of cities can affect the network design and the pumping energy (Petit-Boix et al., 2015; Roux et al., 2011; Sanjuan-Delmás et al., 2015), and a combination of life cycle tools and GIS might provide further knowledge to evaluate water networks at the city scale.

An alternative to urban networks are decentralized strategies (Wa2-Wa5). LCA studies covered specific retrofit technologies (Wa2) (Raluy et al., 2005; Stokes and Horvath, 2009; Tarnacki et al., 2012). To the authors' knowledge, there is a lack of LCC studies for these technologies, albeit the general costs of water were quantified (Karagiannis and Soldatos, 2008). In the context of strategies Wa3, Wa4 and Wa5, more studies apply LCA and LCC while integrating other specific tools such as GIS and hydrologic simulations. Analyses on natural retention systems offer great detail about avoided burdens related to carbon sequestration (De Sousa et al., 2012; Flynn and Traver, 2013; Moore and Hunt, 2013), while providing useful comparisons among different types of green and gray infrastructures. This is also relevant in the studies related to graywater treatment and wastewater recycling alternatives (Wa5), as they mainly compare treatment technologies with rainwater harvesting systems (RWHS) (Anand and Apul, 2011), other green infrastructures (Memon et al., 2007), and conventional wastewater treatment (Benetto et al., 2009; Ng et al., 2014; Remy and Jekel, 2007). With respect to RWHS, there is a clear evolution of the approaches, which began with the integrated impacts of RWHS (Grant and Hallmann, 2003; Roebuck et al., 2010) and evolved to determining the most efficient scenarios in different building densities and locations (Angrill et al., 2012; Devkota et al., 2015; Morales-Pinzón et al., 2012; Vargas-Parra et al., 2014). 
Regarding water and wastewater management, life cycle studies should aim at determining the avoided environmental and economic impacts of their implementation with respect to conventional centralized systems, thereby considering a consequential LCA perspective. Furthermore, multi-functionality of the systems must be better addressed (e.g., RWHS and flood prevention). In addition, assessments at wider scales (i.e., at a neighborhood or watershed level) might enable the comparison of different climatic regions, local policies, traditions and water use patterns. Finally, there is a lack of studies dealing with S-LCA. Only Mcconville (2006) attempted to analyze the social aspects of water and sanitation development projects. Other authors performed multi-criteria assessments (Akhtar et al., 2014; Cruz-Diloné et al., 2014), but the social sphere was not considered. In addition, there is no clear pattern in the use of indicators, i.e., while some authors combine multiple indicators in the assessment (e.g., whole ReCiPe or CML methods) (PetitBoix et al., 2014), others focus on single indicators, particularly GW (Sanjuan-Delmás et al., 2015).

\section{How was urban sustainability evaluated from a life cycle perspective?}

A total of 151 peer-reviewed papers evaluated urban sustainability practices from a life cycle perspective, being the period 2011-2013 and the year 2015 the most productive (Supporting Information 2.1). Table 3 summarizes the number of studies, the coverage of the three sustainability dimensions, type of study and use of indicators for each urban issue.

$<$ Table 3>

Urban sustainability was partially and unevenly evaluated from a life cycle perspective and further research is essential to covering important gaps (Table 2). Water (33\%), waste (17\%) and buildings (16\%) are the urban issues that accounted for the largest amount of studies. However, this review considered only the most relevant LCAs on buildings, since there is a large literature evaluating building materials. On the contrary, a limited number of papers were found for urban planning (4\%) and energy (4\%) (Supporting Information 2.2). However, multiple issues overlap with one another, as relevant interactions occur among them (Figure 2). In particular, urban planning related to all of the remaining issues because it constitutes the fabric where urban activities are developed. For instance, when planning infrastructures in an urban context, the location, design and implementation of urban parks and water networks can affect the sustainability of green areas and water systems. Specific interrelations and examples are provided in Figure 2.

$<$ Figure 2>

From a methodological standpoint, most of the studies (80\%) were exclusively employing LCT tools (LCA, LCC or S-LCA). However, the complexity of urban areas fostered the combination of life cycle tools with other schemes, i.e., environmental input-output tables (economy), GIS, exergy and emergy accounting. Such approach was particularly applied in urban planning, energy and water, although these tools are of interest to all issues.

Regarding sustainability dimensions, LCT studies largely covered the environmental dimension of sustainability through LCA (84\% of the studies). The economic dimension was also approached in LCC- 
standalone studies or a combination of both LCA and LCC (20\%). Only two S-LCA studies were identified for green spaces and waste, respectively. Finally, sustainability as a whole was approached by Vinyes et al. (2012), who performed a LCSA for waste management options. Kennedy et al. (2002) combined environmental and social indicators in a so-called sustainability assessment. Finally, Martinez-Sanchez et al. (2016) evaluated the three dimensions of sustainability from an economic perspective.

These results are also related to the temporal evolution of life cycle tools, as LCA and LCC were developed and standardized in 2006 (ISO 14040:2006) and 2008 (ISO 15686-5:2008), respectively (Supporting Information 2.3). On the contrary, although some methodological guidelines are available for S-LCA (UNEP-SETAC, 2009) and LCSA (UNEP-SETAC, 2011), there is still neither consensus nor standardization. In particular, Martínez-Blanco et al. (2015) highlighted the multiple challenges that practitioners face in the implementation of S-LCA at the product level, as several indicators of the current S-LCA scheme evaluate the organizational and country levels. Thus, there is a need to re-think the current S-LCA approach for products and services by developing new indicators related to their functions instead of organizations and countries.

Between 10 and $33 \%$ of the studies only evaluated the $\mathrm{GW}$ indicator due to the significance of $\mathrm{CO}_{2}$ emissions not only at the scientific but also at the public spheres (e.g., mass media). On the contrary, the use of a more complete set of indicators to minimize trade-offs among impact categories was performed in studies regarding green spaces $(90 \%)$ and mobility (80\%). However, the employment of a set of indicators limits the prioritization criteria in comparisons and the outreach of the results to the citizens.

\section{Evaluating the city as a unique system}

Notwithstanding the high interdependence between the urban issues and sustainability strategies evaluated (Figure 2), cities have not been analyzed comprehensively from a life cycle perspective so far due to its complexity. At the city scale, quantitative studies usually assessed the urban metabolism (UM) as a global system (Browne et al., 2009; Chen and Chen, 2012; Kennedy and Hoornweg, 2012; Pincetl et al., 2012; Sahely et al., 2003), paying particular attention to the consequent urban carbon emissions (Kennedy et al., 2010, 2009; Sugar et al., 2012). Particularly for GHG, city-scale LCA worked on further developing methods that deepen in the sources of such environmental burdens. For instance, Ramaswami et al. (2008) elaborated a demand-centered hybrid life-cycle-based methodology. The model differentiates direct (i.e., buildings electricity use, buildings natural gas and surface travel) and indirect flows (i.e., airline travel, fuel production, cement use, food purchase). For the city of Denver (United States), this method quantified a yearly emission of $25 \mathrm{t}$ of $\mathrm{CO}_{2}$ per inhabitant.

Some authors combined UM with LCA. While UM quantifies the flows within the city limits (i.e., direct consumption of resources and production of emissions and waste), LCA evaluates the impacts of urban components from cradle to grave, thereby considering their embedded environmental burdens. Chester et al. (2012) proposed a method for evaluating the sustainability of cities by merging UM and LCA together with socio-demographic data at the neighborhood scale. Goldstein et al. (2013) demonstrated that combining UM and LCA leads to larger volumes of mass and energy flows, compared to conventional UM. 
For most of the case studies, the embedded impacts identified with the LCA framework accounted for more than $50 \%$ of the global results. Values ranged from 10.2 to 18.0 t of $\mathrm{CO}_{2}$ eq. per capita and year.

Therefore, LCT showed some limitations in approaching the evaluation of cities as a whole unless being integrated into other industrial ecology tools. Notwithstanding this constraint, urban policies tend to address each issue separately, since each urban problem is treated by different public offices and even at different scales (from national to local policies). Hence, issue-specific LCT studies can still provide policy-makers with information and data to assess each issue and strategy.

\section{Conclusions and research gaps}

Unlike other systems, the complexity of cities makes them difficult to be analyzed comprehensively. Furthermore, the thorough analysis of its subsystems is of interest because they have substantial environmental burdens and provides basic services to more than $50 \%$ of the world's population. For this reason, a review of what has been done using LCT is of interest to provide an adequate framework and detect research gaps that facilitate future research. LCT studies can assist in the definition and prioritization of strategies towards urban sustainability, particularly for policy purposes (i.e., from the regional to the local level). A life cycle approach is essential to avoiding different types of trade-offs, i.e., (a) spatial (e.g., energy consumption affects impacts in energy production sites beyond city boundaries); (b) among life cycle stages (e.g., materials extraction for urban elements), and (c) indicators (e.g., GW and local impacts on freshwater). In this paper, a literature review on urban sustainability and life cycle studies was performed with the aim of illustrating the current situation and identifying research gaps for further research.

To do so, we identified the strategies towards sustainability defined for each urban issue, which should be promoted by decision-makers (e.g., local authorities, urban planners, designers, etc.). In general, these strategies lead to a functional mimicry of natural systems in urban spaces through systems that foster sustainability. This can be achieved through direct processes, namely including green infrastructure in cities that can enhance resource efficiency in multiple urban issues, i.e., water (e.g., stormwater management), energy (e.g., thermal insulation), urban planning (e.g., urban lungs), food (e.g., local production) and green areas (e.g., urban heat island). On the other hand, indirect processes emulate ecological mechanisms to optimize the urban metabolism, such as recycling or renewable energy systems. Therefore, renaturalization strategies might be the focus of political agendas towards sustainable cities, as shown in global programs (e.g., promotion of circular economy in European policy).

However, the review highlighted the actions needed for a better assessment of urban sustainability from a life cycle perspective. On the one hand, several urban issues (e.g., energy, mobility, urban planning, food) are partially evaluated, while some of the strategies were not yet addressed, such as increasing the use of ITS or addressing energy affordability. On the other hand, the methodological development of life cycle tools calls for particular attention at different levels. First, integrated schemes that combine life cycle tools with other methodologies can assist in the evaluation of the urban complexity, particularly for those issues that require assessment at a larger scale (e.g., neighborhood, city, economy), such as mobility or water. Second, evaluating sustainability may require analyzing its three dimensions in a comprehensive manner, i.e., environment, society and economy. For this purpose, current methodologies for S-LCA and LCSA 
should be revised to enhance their implementation in case studies. Finally, although some studies covered important research gaps, the authors focused on the indicators of GW or energy consumption thereby limiting the understanding of some sustainability strategies.

Further research might cover the current research gaps in both thematic and methodological terms. Efforts might focus on urban issues with a limited availability of life cycle information and data, as well as overlaps among different issues. Advances in methods might work on three aspects: (1) identification and development of the best integrated schemes to model and assess the complexity of urban issues, (2) progress in the implementation of sustainability studies from a comprehensive perspective (i.e., covering the three dimensions of sustainability), and (3) promotion of multi-indicators for minimizing the potential trade-offs among impact categories. Beyond such aspects, life cycle tools would generally benefit from revising the methodology with stakeholders to optimize the understanding and communication of life cycle results for policy- and decision-making processes.

\section{Acknowledgements}

The authors thank the Spanish Ministry of Education for awarding research scholarships to E. SanyéMengual (AP2010-4044), A. Petit-Boix (FPU13/01273) and Generalitat de Catalunya for awarding research scholarships to P. Llorach-Massana (FI-DGR 2015) and D. Sanjuan-Delmás (FI-DGR 2014). We would like also to thank the University Center of Defense from Zaragoza for the financial support of the project 2015-11 to Jorge Sierra-Pérez. Thanks to the Catalan Government for the SGR funds (2014 SGR 1412). We acknowledge the financial support from the Spanish Ministry of Economy and Competitiveness, through the "María de Maeztu" program for Units of Excellence in R\&D (MDM-2015-0552).

\section{References}

Agrawal, B., Tiwari, G.N., 2010. Life cycle cost assessment of building integrated photovoltaic thermal (BIPVT) systems. Energy Build. 42, 1472-1481. doi:10.1016/j.enbuild.2010.03.017

Akhtar, S., Reza, B., Hewage, K., Shahriar, A., Zargar, A., Sadiq, R., 2014. Life cycle sustainability assessment (LCSA) for selection of sewer pipe materials. Clean Technol. Environ. Policy 17, 973992. doi:10.1007/s10098-014-0849-x

Allen, S.R., Hammond, G.P., McManus, M.C., 2008. Energy analysis and environmental life cycle assessment of a micro-wind turbine. Proc. Inst. Mech. Eng. Part A J. Power Energy 222, 669-684. doi:10.1243/09576509JPE538

Allenby, B., 2009. The Industrial Ecology of Emerging Technologies. J. Ind. Ecol. 13, 168-183. doi:10.1111/j.1530-9290.2009.00114.x

Ally, J., Pryor, T., 2008. Life Cycle Assessment (LCA) of the Hydrogen Fuel Cell, Natural Gas, and Diesel Bus Transportation Systems in Western Australia [WWW Document]. Perth, West. Aust. Dep. Plan. Infrastructure.

Anand, C., Apul, D.S., 2011. Economic and environmental analysis of standard, high efficiency, rainwater flushed, and composting toilets. J. Environ. Manage. 92, 419-28. doi:10.1016/j.jenvman.2010.08.005

Angrill, S., Farreny, R., Gasol, C.M., Gabarrell, X., Viñolas, B., Josa, A., Rieradevall, J., 2012. 
Environmental analysis of rainwater harvesting infrastructures in diffuse and compact urban models of Mediterranean climate. Int. J. Life Cycle Assess. 17, 25-42. doi:10.1007/s11367-011-0330-6

Ardente, F., Beccali, M., Cellura, M., Mistretta, M., 2008. Building energy performance: A LCA case study of kenaf-fibres insulation board. Energy Build. 40, 1-10. doi:10.1016/j.enbuild.2006.12.009

Arena, U., Mastellone, M.L., Perugini, F., 2003. The environmental performance of alternative solid waste management options: A life cycle assessment study. Chem. Eng. J. 96, 207-222. doi:10.1016/j.cej.2003.08.019

Assiego de Larriva, R., Calleja Rodríguez, G., Cejudo López, J.M., Raugei, M., Fullana i Palmer, P., 2014. A decision-making LCA for energy refurbishment of buildings: Conditions of comfort. Energy Build. 70, 333-342. doi:10.1016/j.enbuild.2013.11.049

Astee, L.Y., Kishnani, N.T., 2010. Building Integrated Agriculture: Utilising Rooftops for Sustainable Food Crop Cultivation in Singapore. J. Green Build. 5, 105-113. doi:10.3992/jgb.5.2.105

Balocco, C., Papeschi, S., Grazzini, G., Basosi, R., 2004. Using exergy to analyze the sustainability of an urban area. Ecol. Econ. 48, 231-244. doi:10.1016/j.ecolecon.2003.08.006

Baró, F., Chaparro, L., Gómez-Baggethun, E., Langemeyer, J., Nowak, D.J., Terradas, J., 2014. Contribution of ecosystem services to air quality and climate change mitigation policies: the case of urban forests in Barcelona, Spain. Ambio 43, 466-79. doi:10.1007/s13280-014-0507-X

Beavis, P., Lundie, S., 2003. Integrated environmental assessment of tertiary and residuals treatment LCA in the wastewater industry, in: Water Science and Technology. pp. 109-116.

Benetto, E., Nguyen, D., Lohmann, T., Schmitt, B., Schosseler, P., 2009. Life cycle assessment of ecological sanitation system for small-scale wastewater treatment. Sci. Total Environ. 407, 150616. doi:10.1016/j.scitotenv.2008.11.016

Berggren, B., Hall, M., Wall, M., 2013. LCE analysis of buildings - Taking the step towards Net Zero Energy Buildings. Energy Build. 62, 381-391. doi:10.1016/j.enbuild.2013.02.063

Bianchini, F., Hewage, K., 2012. How "green” are the green roofs? Lifecycle analysis of green roof materials. Build. Environ. 48, 57-65. doi:10.1016/j.buildenv.2011.08.019

Blengini, G.A., 2009. Life cycle of buildings, demolition and recycling potential: A case study in Turin, Italy. Build. Environ. 44, 319-330. doi:10.1016/j.buildenv.2008.03.007

Blom, I., Itard, L., Meijer, A., 2011. Environmental impact of building-related and user-related energy consumption in dwellings. Build. Environ. 46, 1657-1669. doi:10.1016/j.buildenv.2011.02.002

Blom, I., Itard, L., Meijer, A., 2010a. LCA-based environmental assessment of the use and maintenance of heating and ventilation systems in Dutch dwellings. Build. Environ. 45, 2362-2372. doi:10.1016/j.buildenv.2010.04.012

Blom, I., Itard, L., Meijer, A., 2010b. Environmental impact of dwellings in use: Maintenance of façade components. Build. Environ. 45, 2526-2538. doi:10.1016/j.buildenv.2010.05.015

Browne, D., O’Regan, B., Moles, R., 2009. Assessment of total urban metabolism and metabolic inefficiency in an Irish city-region. Waste Manag. 29, 2765-71. doi:10.1016/j.wasman.2009.05.008

Buttol, P., Masoni, P., Bonoli, a., Goldoni, S., Belladonna, V., Cavazzuti, C., 2007. LCA of integrated MSW management systems: Case study of the Bologna District. Waste Manag. 27, 1059-1070. doi:10.1016/j.wasman.2007.02.010 
Cao, Y., Pawłowski, A., 2013. Life cycle assessment of two emerging sewage sludge-to-energy systems: evaluating energy and greenhouse gas emissions implications. Bioresour. Technol. 127, 81-91. doi:10.1016/j.biortech.2012.09.135

Cerón-Palma, I., Sanyé-Mengual, E., Oliver-Solà, J., Montero, J.-I., Ponce-Caballero, C., Rieradevall, J., 2013. Towards a green sustainable strategy for social neighbourhoods in Latin America: Case from social housing in Merida, Yucatan, Mexico. Habitat Int. 38, 47-56. doi:10.1016/j.habitatint.2012.09.008

Chen, S., Chen, B., 2012. Network Environ Perspective for Urban Metabolism and Carbon Emissions: A Case Study of Vienna, Austria. Environ. Sci. Technol. 46, 4498-4506. doi:10.1021/es204662k

Cherry, C.R., Weinert, J.X., Xinmiao, Y., 2009. Comparative environmental impacts of electric bikes in China. Transp. Res. Part D Transp. Environ. 14, 281-290. doi:10.1016/j.trd.2008.11.003

Chester, M., Pincetl, S., Allenby, B., 2012. Avoiding unintended tradeoffs by integrating life-cycle impact assessment with urban metabolism. Curr. Opin. Environ. Sustain. 4, 451-457. doi:10.1016/j.cosust.2012.08.004

Chiavetta, C., Tinti, F., Bonoli, A., 2011. Comparative life cycle assessment of renewable energy systems for heating and cooling. Procedia Eng. 21, 591-597. doi:10.1016/j.proeng.2011.11.2054

Cleary, J., 2014. A life cycle assessment of residential waste management and prevention. Int. J. Life Cycle Assess. 19, 1607-1622. doi:10.1007/s11367-014-0767-5

Çomakl1, K., Yüksel, B., 2003. Optimum insulation thickness of external walls for energy saving. Appl. Therm. Eng. 23, 473-479. doi:10.1016/S1359-4311(02)00209-0

Corominas, L., Foley, J., Guest, J.S., Hospido, A., Larsen, H.F., Morera, S., Shaw, A., 2013. Life cycle assessment applied to wastewater treatment: state of the art. Water Res. 47, 5480-92. doi:10.1016/j.watres.2013.06.049

Cruz-Diloné, P., Thorn, B.K., Brownell, S., 2014. A Life-Cycle Comparison of Selected Sanitation Alternatives for Developing Countries, in: Proceedings of the 2014 Industrial and Systems Engineering Research Conference. Montréal, Canada.

de Gracia, A., Rincón, L., Castell, A., Jiménez, M., Boer, D., Medrano, M., Cabeza, L.F., 2010. Life Cycle Assessment of the inclusion of phase change materials (PCM) in experimental buildings. Energy Build. 42, 1517-1523. doi:10.1016/j.enbuild.2010.03.022

de Meester, T., Marique, A.-F., De Herde, A., Reiter, S., 2013. Impacts of occupant behaviours on residential heating consumption for detached houses in a temperate climate in the northern part of Europe. Energy Build. 57, 313-323. doi:10.1016/j.enbuild.2012.11.005

De Sousa, M.R.C., Montalto, F.A., Spatari, S., 2012. Using Life Cycle Assessment to Evaluate Green and Grey Combined Sewer Overflow Control Strategies. J. Ind. Ecol. 16, 901-913. doi:10.1111/j.15309290.2012.00534.x

Densley Tingley, D., Davison, B., 2012. Developing an LCA methodology to account for the environmental benefits of design for deconstruction. Build. Environ. 57, 387-395. doi:10.1016/j.buildenv.2012.06.005

Devkota, J., Schlachter, H., Apul, D., 2015. Life Cycle Based Evaluation of Harvested Rainwater Use in Toilets and for Irrigation. J. Clean. Prod. doi:10.1016/j.jclepro.2015.02.021 
Dodoo, A., Gustavsson, L., 2013. Life cycle primary energy use and carbon footprint of wood-frame conventional and passive houses with biomass-based energy supply. Appl. Energy 112, 834-842. doi:10.1016/j.apenergy.2013.04.008

Edwards-Jones, G., Milà i Canals, L., Hounsome, N., Truninger, M., Koerber, G., Hounsome, B., Cross, P., York, E.H., Hospido, A., Plassmann, K., Harris, I.M., Edwards, R.T., Day, G. a. S., Tomos, a. D., Cowell, S.J., Jones, D.L., 2008. Testing the assertion that "local food is best": the challenges of an evidence-based approach. Trends Food Sci. Technol. 19, 265-274.

doi:10.1016/j.tifs.2008.01.008

EIP-SCC. European Innovation Partnership on Smart Cities and Communities, 2016. Market Place of the European Innovation Partnership on Smart Cities and Communities. https://eusmartcities.eu/content/overview-our-initiatives [WWW Document].

Elkinton, M.R., McGowan, J.G., Manwell, J.F., 2009. Wind power systems for zero net energy housing in the United States. Renew. Energy 34, 1270-1278. doi:10.1016/j.renene.2008.10.007

European Commission, 2016a. Horizon 2020 Sections. http://ec.europa.eu/programmes/horizon2020/h2020-sections [WWW Document].

European Commission, 2016b. European Initiative on Smart Cities. SETIS, Strategic Energy Technologies Information System. https://setis.ec.europa.eu/set-plan-implementation/technologyroadmaps/european-initiative-smart-cities [WWW Document].

European Commission, 2010a. Making sustainable consumption and production a reality. A guide for business and policy makers to Life Cycle Thinking and Assessment. Luxembourg.

European Commission, 2010b. World and European Sustainable Cities. Insights from EU research. http://ec.europa.eu/research/social-sciences/pdf/policy_reviews/sustainable-cities-report_en.pdf. Brussels, Belgium.

Feo, G.D., Malvano, C., 2009. The use of LCA in selecting the best MSW management system. Waste Manag. 29, 1901-1915. doi:10.1016/j.wasman.2008.12.021

Finkbeiner, M., Schau, E.M., Lehmann, A., Traverso, M., 2010. Towards Life Cycle Sustainability Assessment. Sustainability 2, 3309-3322. doi:10.3390/su2103309

Flynn, K.M., Traver, R.G., 2013. Green infrastructure life cycle assessment: A bio-infiltration case study. Ecol. Eng. 55, 9-22. doi:10.1016/j.ecoleng.2013.01.004

Gentil, E.C., Gallo, D., Christensen, T.H., 2011. Environmental evaluation of municipal waste prevention. Waste Manag. 31, 2371-2379. doi:10.1016/j.wasman.2011.07.030

Goldstein, B., Birkved, M., Quitzau, M.-B., Hauschild, M., 2013. Quantification of urban metabolism through coupling with the life cycle assessment framework: concept development and case study. Environ. Res. Lett. 8, 35024. doi:10.1088/1748-9326/8/3/035024

Grant, T., Hallmann, M., 2003. Urban Domestic Water Tanks : Life Cycle Assessment. Water 22-27.

Guinée, J.B., Heijungs, R., Huppes, G., Zamagni, A., Masoni, P., Buonamici, R., Ekvall, T., Rydberg, T., 2011. Life cycle assessment: past, present, and future. Environ. Sci. Technol. 45, 90-6. doi:10.1021/es101316v

Harvey, D., 2009. Social Justice in the City, Interventions. doi:10.1111/j.1467-8330.1972.tb00486.x

Heinonen, J., Junnila, S., 2011. Implications of urban structure on carbon consumption in metropolitan 
areas. Environ. Res. Lett. 6, 14018. doi:10.1088/1748-9326/6/1/014018

Herva, M., Neto, B., Roca, E., 2014. Environmental assessment of the integrated municipal solid waste management system in Porto (Portugal). J. Clean. Prod. 70, 183-193.

doi:10.1016/j.jclepro.2014.02.007

Hospido, A., Moreira, M.T., Feijoo, G., 2008. A Comparison of Municipal Wastewater Treatment Plants for Big Centres of Population in Galicia ( Spain ). Int. J. Life Cycle Assess. 13, 57-64.

Hosseinijou, S.A., Mansour, S., Shirazi, M.A., 2013. Social life cycle assessment for material selection: a case study of building materials. Int. J. Life Cycle Assess. 19, 620-645. doi:10.1007/s11367-0130658-1

Hutyra, L.R., Yoon, B., Alberti, M., 2011. Terrestrial carbon stocks across a gradient of urbanization: A study of the Seattle, WA region. Glob. Chang. Biol. 17, 783-797. doi:10.1111/j.1365-

2486.2010.02238.x

IDAE. Instituto para la Diversificación y Ahorro de la Energía, 2012. "Smart Cities” Technology Map (Mapa tecnológico "Ciudades Inteligentes").

http://www.idae.es/uploads/documentos/documentos_Borrador_Smart_Cities_18_Abril_2012_b97f 8b15.pdf.

Institute for Sustainable Communities, 2017. Definition of Sustainable Community. http://www.iscvt.org/impact/definition-sustainable-community/ [WWW Document].

Iriarte, A., Gabarrell, X., Rieradevall, J., 2009. LCA of selective waste collection systems in dense urban areas. Waste Manag. 29, 903-914. doi:10.1016/j.wasman.2008.06.002

ISO 14040:2006, n.d. Environmental management - Life cycle assessment - Principles and framework.

ISO 15686-5:2008, n.d. Buildings and constructed assets - Sevice-life planning - Part 5: Life-cycle costing.

Jo, H.-K., 2002. Impacts of urban greenspace on offsetting carbon emissions for middle Korea. J. Environ. Manage. 64, 115-126. doi:10.1006/jema.2001.0491

Johnson, E.P., 2011. Air-source heat pump carbon footprints: HFC impacts and comparison to other heat sources. Energy Policy 39, 1369-1381. doi:10.1016/j.enpol.2010.12.009

Jones, A., 2002. An environmental assessment of food supply chains: a case study on dessert apples. Environ. Manage. 30, 560-76.

Karagiannis, I.C., Soldatos, P.G., 2008. Water desalination cost literature: review and assessment. Desalination 223, 448-456. doi:10.1016/j.desal.2007.02.071

Kennedy, C.A., 2002. A comparison of the sustainability of public and private transportation syste ... Transportation (Amst). 29, 459-493. doi:10.1023/A:1016302913909

Kennedy, C., Baker, L., Dhakal, S., Ramaswami, A., 2012. Sustainable Urban Systems: An Integrated Approach. J. Ind. Ecol. 16, 775-779. doi:10.1111/j.1530-9290.2012.00564.x

Kennedy, C., Hoornweg, D., 2012. Mainstreaming Urban Metabolism. J. Ind. Ecol. 16, 780-782. doi:10.1111/j.1530-9290.2012.00548.x

Kennedy, C., Steinberger, J., Gasson, B., Hansen, Y., Hillman, T., Havránek, M., Pataki, D., Phdungsilp, A., Ramaswami, A., Mendez, G.V., 2010. Methodology for inventorying greenhouse gas emissions from global cities. Energy Policy 38, 4828-4837. doi:10.1016/j.enpol.2009.08.050 
Kennedy, C., Steinberger, J., Gasson, B., Hansen, Y., Hillman, T., Havránek, M., Pataki, D., Phdungsilp, A., Ramaswami, A., Mendez, G.V., 2009. Greenhouse Gas Emissions from Global Cities. Environ. Sci. Technol. 43, 7297-7302. doi:10.1021/es900213p

Koroneos, C., Tsarouhis, M., 2012. Exergy analysis and life cycle assessment of solar heating and cooling systems in the building environment. J. Clean. Prod. 32, 52-60. doi:10.1016/j.jclepro.2012.03.012

Kosareo, L., Ries, R., 2007. Comparative environmental life cycle assessment of green roofs. Build. Environ. 42, 2606-2613. doi:10.1016/j.buildenv.2006.06.019

Kulak, M., Graves, A., Chatterton, J., 2013. Reducing greenhouse gas emissions with urban agriculture: A Life Cycle Assessment perspective. Landsc. Urban Plan. 111, 68-78. doi:10.1016/j.landurbplan.2012.11.007

Lave, L., MacLean, H., Hendrickson, C., Lankey, R., 2000. Life-cycle analysis of alternative automobile fuel/propulsion technologies. Environ. Sci. Technol. 34, 3598-3605. doi:10.1021/es991322+

Li, D., Wang, R., 2009. Hybrid Emergy-LCA (HEML) based metabolic evaluation of urban residential areas: The case of Beijing, China. Ecol. Complex. 6, 484-493. doi:10.1016/j.ecocom.2009.09.002

Loiseau, E., Roux, P., Junqua, G., Maurel, P., Bellon-Maurel, V., 2013. Adapting the LCA framework to environmental assessment in land planning. Int. J. Life Cycle Assess. 18, 1533-1548. doi:10.1007/s11367-013-0588-y

Lucas, A., Neto, R.C., Silva, C.A., 2013. Energy supply infrastructure LCA model for electric and hydrogen transportation systems. Energy 56, 70-80. doi:10.1016/j.energy.2013.04.056

Lundin, M., Bengtsson, M., Molander, S., 2000. Life Cycle Assessment of Wastewater Systems: Influence of System Boundaries and Scale on Calculated Environmental Loads. Environ. Sci. Technol. 34, 180-186. doi:10.1021/es990003f

Macombe, C., Leskinen, P., Feschet, P., Antikainen, R., 2013. Social life cycle assessment of biodiesel production at three levels: a literature review and development needs. J. Clean. Prod. 52, 205-216. doi:10.1016/j.jclepro.2013.03.026

Martínez-Blanco, J., Lehmann, A., Chang, Y.-J., Finkbeiner, M., 2015. Social organizational LCA (SOLCA) - a new approach for implementing social LCA. Int. J. Life Cycle Assess. 20, 15861599. doi:10.1007/s11367-015-0960-1

Martinez-Sanchez, V., Tonini, D., Møller, F., Astrup, T.F., 2016. Life-Cycle Costing of Food Waste Management in Denmark: Importance of Indirect Effects. Environ. Sci. Technol. 50, 4513-4523. doi:10.1021/acs.est.5b03536

Mcconville, J.R., 2006. Applying Life Cycle Thinking to International Water and Sanitation Development Projects : An assessment tool for project managers in sustainable development work.

Memon, F.A., Zheng, Z., Butler, D., Shirley-Smith, C., Lui, S., Makropoulos, C., Avery, L., 2007. Life cycle impact assessment of greywater recycling technologies for new developments. Environ. Monit. Assess. 129, 27-35. doi:10.1007/s10661-006-9422-3

Mendoza, J.-M., Josa, A., Rieradevall, J., Gabarrell, X., 2016. Environmental Impact of Public Charging Facilities for Electric Two-Wheelers. J. Ind. Ecol. 20, 54-66.

Mendoza, J.M.F., Sanyé-Mengual, E., Angrill, S., García-Lozano, R., Feijoo, G., Josa, A., Gabarrell, X., Rieradevall, J., 2015. Development of urban solar infrastructure to support low-carbon mobility. 
Energy Policy 85, 102-114. doi:10.1016/j.enpol.2015.05.022

Menzies, G., Turan, S., Banfill, P., 2007. LCA, methodologies, inventories and embodied energy: a review. Constr. Mater 160, 135-143.

Merrild, H., Larsen, A.W., Christensen, T.H., 2012. Assessing recycling versus incineration of key materials in municipal waste: The importance of efficient energy recovery and transport distances. Waste Manag. 32, 1009-1018. doi:10.1016/j.wasman.2011.12.025

Monahan, J., Powell, J.C., 2011. An embodied carbon and energy analysis of modern methods of construction in housing: A case study using a lifecycle assessment framework. Energy Build. 43, 179-188. doi:10.1016/j.enbuild.2010.09.005

Moore, T.L.C., Hunt, W.F., 2013. Predicting the carbon footprint of urban stormwater infrastructure. Ecol. Eng. 58, 44-51. doi:10.1016/j.ecoleng.2013.06.021

Morales-Pinzón, T., Lurueña, R., Rieradevall, J., Gasol, C.M., Gabarrell, X., 2012. Financial feasibility and environmental analysis of potential rainwater harvesting systems: A case study in Spain. Resour. Conserv. Recycl. 69, 130-140. doi:10.1016/j.resconrec.2012.09.014

Morgan, K., 2009. Feeding the City: The Challenge of Urban Food Planning. Int. Plan. Stud. 14, 341348. doi:10.1080/13563471003642852

Morselli, L., De Robertis, C., Luzi, J., Passarini, F., Vassura, I., 2008. Environmental impacts of waste incineration in a regional system (Emilia Romagna, Italy) evaluated from a life cycle perspective. J. Hazard. Mater. 159, 505-511. doi:10.1016/j.jhazmat.2008.02.047

Muñoz, I., Milà-I-Canals, L., Fernández-Alba, A.R., 2010. Life Cycle Assessment of Water Supply Plans in Mediterranean Spain: The Ebro River Transfer Versus the AGUA Programme. J. Ind. Ecol. 14, 902-918. doi:10.1111/j.1530-9290.2010.00271.x

Nahlik, M.J., Chester, M. V., 2014. Transit-oriented smart growth can reduce life-cycle environmental impacts and household costs in Los Angeles. Transp. Policy 35, 21-30. doi:10.1016/j.tranpol.2014.05.004

Nessi, S., Rigamonti, L., Grosso, M., 2015. Packaging waste prevention activities: A life cycle assessment of the effects on a regional waste management system. Waste Manag. Res. 33, 833-49. doi:10.1177/0734242X15587736

Nessi, S., Rigamonti, L., Grosso, M., 2012. LCA of waste prevention activities: A case study for drinking water in Italy. J. Environ. Manage. 108, 73-83. doi:10.1016/j.jenvman.2012.04.025

Nethersole, A., Harkay, P., Tookey, M., Gray, M., Bouquet, A., Saunders, J., 2012. Sustainable Cities. Building Cities for the Future. Climate Action, London.

Ng, B.J.H., Zhou, J., Giannis, A., Chang, V.W.-C., Wang, J.-Y., 2014. Environmental life cycle assessment of different domestic wastewater streams: policy effectiveness in a tropical urban environment. J. Environ. Manage. 140, 60-8. doi:10.1016/j.jenvman.2014.01.052

Nicolae, B., George-Vlad, B., 2015. Life cycle analysis in refurbishment of the buildings as intervention practices in energy saving. Energy Build. 86, 74-85. doi:10.1016/j.enbuild.2014.10.021

Norman, J., MacLean, H.L., Kennedy, C.A., 2006. Comparing High and Low Residential Density: LifeCycle Analysis of Energy Use and Greenhouse Gas Emissions. J. Urban Plan. Dev. 132, 10-21. doi:10.1061/(ASCE)0733-9488(2006)132:1(10) 
Nowak, D.J., 1994. Atmospheric carbon dioxide reduction by Chicago's urban forest., in: Chicago's Urban Forest Ecosystem: Results of the Chicago Urban Forest Climate Project.Ir. pp. 83-94.

Oliver-Solà, J., Gabarrell, X., Rieradevall, J., 2009. Environmental impacts of natural gas distribution networks within urban neighborhoods. Appl. Energy 86, 1915-1924. doi:10.1016/j.apenergy.2008.11.029

Oliver-Sola, J., Nunez, M., Gabarrell, X., Boada, M., Rieradevall, J., 2007. Service sector metabolism Accounting for energy impacts of the Montjuic Urban Park in Barcelona. J. Ind. Ecol. 11, 83-98. doi:10.1162/jie.2007.1193

Onat, N.C., Kucukvar, M., Tatari, O., 2014. Integrating triple bottom line input-output analysis into life cycle sustainability assessment framework: the case for US buildings. Int. J. Life Cycle Assess. 19, 1488-1505. doi:10.1007/s11367-014-0753-y

Pagoni, I., Schafer, A., Psaraki, V., 2012. Techno-economic assessment of the potential of intelligent transport systems to reduce CO2 emissions. IET Intell. Transp. Syst. 6, 355-363. doi:10.1049/ietits.2012.0056

Pasqualino, J.C., Meneses, M., Abella, M., Castells, F., 2009. LCA as a decision support tool for the environmental improvement of the operation of a municipal wastewater treatment plant. Environ. Sci. Technol. 43, 3300-7.

Payen, S., Basset-Mens, C., Perret, S., 2015. LCA of local and imported tomato: an energy and water trade-off. J. Clean. Prod. 87, 139-148. doi:10.1016/j.jclepro.2014.10.007

Peri, G., Traverso, M., Finkbeiner, M., Rizzo, G., 2012a. Embedding “substrate” in environmental assessment of green roofs life cycle: Evidences from an application to the whole chain in a Mediterranean site. J. Clean. Prod. 35, 274-287. doi:10.1016/j.jclepro.2012.05.038

Peri, G., Traverso, M., Finkbeiner, M., Rizzo, G., 2012b. The cost of green roofs disposal in a life cycle perspective: Covering the gap. Energy 48, 406-414. doi:10.1016/j.energy.2012.02.045

Peri, G., Traverso, M., Finkbeiner, M., Rizzo, G., 2010. Un possibile aproccio “Social LCA” per le coperture a verde, Ecomondo 2010 “Ambiente-Economia Nel cuore delle azioni."

Petit-Boix, A., Sanjuan-Delmás, D., Chenel, S., Marín, D., Gasol, C., Farreny, R., Villalba, G., SuárezOjeda, M., Gabarrell, X., Josa, A., Rieradevall, J., 2015. Assessing the energetic and environmental impacts of the operation and maintenance of Spanish sewer networks from a life-cycle perspective. Water Resour. Manag. 29, 2581-2597. doi:10.1007/s11269-015-0958-2

Petit-Boix, A., Sanjuan-Delmás, D., Gasol, C., Villalba, G., Suárez-Ojeda, M., Gabarrell, X., Josa, A., Rieradevall, J., 2014. Environmental Assessment of Sewer Construction in Small to Medium Sized Cities Using Life Cycle Assessment. Water Resour. Manag. 28, 979-997. doi:10.1007/s11269-0140528-z

Pincetl, S., Bunje, P., Holmes, T., 2012. An expanded urban metabolism method: Toward a systems approach for assessing urban energy processes and causes. Landsc. Urban Plan. 107, 193-202. doi:10.1016/j.landurbplan.2012.06.006

Porsche, U., Köhler, M., 2003. LIFE CYCLE COSTS OF GREEN ROOFS - A Comparison of Germany, USA, and Brazil. RIO 3 - World Clim. Energy Event 1-5. doi:10.1007/s00158-009-0416-y President's Council on Sustainable Development, 1998. Sustainable Communities Task Force report. 
Washington, DC.

Racoviceanu, A.I., Karney, B.W., Asce, M., Kennedy, C.A., Colombo, A.F., 2007. Life-Cycle Energy Use and Greenhouse Gas Emissions Inventory for Water Treatment Systems. J. Infrastruct. Syst. 13, 261-270. doi:10.1061/(ASCE)1076-0342(2007)13:4(261)

Raluy, R.G., Serra, L., Uche, J., 2005. Life cycle assessment of desalination technologies integrated with renewable energies. Desalination 183, 81-93. doi:10.1016/j.desal.2005.04.023

Ramaswami, A., Hillman, T., Janson, B., Reiner, M., Thomas, G., 2008. A Demand-Centered, Hybrid Life-Cycle Methodology for City-Scale Greenhouse Gas Inventories. Environ. Sci. Technol. 42, 6455-6461. doi:10.1021/es702992q

Remy, C., Jekel, M., 2007. Ecological assessment of selected alternative sanitation concepts via Life Cycle Assessment, in: 3rd International Conference on Life Cycle Management. Zurich, Switzerland.

Ristimäki, M., Säynäjoki, A., Heinonen, J., Junnila, S., 2013. Combining life cycle costing and life cycle assessment for an analysis of a new residential district energy system design. Energy 63, 168-179. doi:10.1016/j.energy.2013.10.030

Roebuck, R., Oltean-Dumbrava, C., Tait, S., 2010. Whole life cost performance of domestic rainwater harvesting systems in the United Kingdom. Water Environ. J. doi:10.1111/j.17476593.2010.00230.x

Rosenbaum, R.K., Bachmann, T.M., Gold, L.S., Huijbregts, M. a J., Jolliet, O., Juraske, R., Koehler, A., Larsen, H.F., MacLeod, M., Margni, M., McKone, T.E., Payet, J., Schuhmacher, M., Van De Meent, D., Hauschild, M.Z., 2008. USEtox - The UNEP-SETAC toxicity model: Recommended characterisation factors for human toxicity and freshwater ecotoxicity in life cycle impact assessment. Int. J. Life Cycle Assess. 13, 532-546. doi:10.1007/s11367-008-0038-4

Roux, P., Mur, I., Risch, E., Boutin, C., 2011. Urban planning of sewer infrastructure : Impact of population density and land topography on environmental performances of wastewater treatment systems., in: Presented at the Life Cycle Conference 2011, "Policy: LCM in Public Policy" Session, Berlin.

Sahely, H.R., Dudding, S., Kennedy, C.A., 2003. Estimating the urban metabolism of Canadian cities: Greater Toronto Area case study. Can. J. Civ. Eng. 30, 468-483. doi:10.1139/102-105

Saiz, S., Kennedy, C., Bass, B., Pressnail, K., 2006. Comparative life cycle assessment of standard and green roofs. Environ. Sci. Technol. 40, 4312-6.

Sanjuan-Delmás, D., Petit-Boix, A., Gasol, C., Villalba, G., Suárez-Ojeda, M., Gabarrell, X., Josa, A., Rieradevall, J., 2014. Environmental assessment of different pipelines for drinking water transport and distribution network in small to medium cities: a case from Betanzos, Spain. J. Clean. Prod. 66, 588-598. doi:10.1016/j.jclepro.2013.10.055

Sanjuan-Delmás, D., Petit-Boix, A., Gasol, C.M., Farreny, R., Villalba, G., Suárez-Ojeda, M.E., Gabarrell, X., Josa, A., Rieradevall, J., 2015. Environmental assessment of drinking water transport and distribution network use phase for small to medium-sized municipalities in Spain. J. Clean.

Prod. 87, 573-582. doi:10.1016/j.jclepro.2014.09.042

Sanyé-Mengual, E., Cerón-Palma, I., Oliver-Solà, J., Montero, J., Rieradevall, J., 2015a. Integrating 
horticulture into cities: A guide for assessing the implementation potential of Rooftop Greenhouses (RTGs) in industrial and logistics parks. J. Urban Technol. 22, 87-111.

Sanyé-Mengual, E., Oliver-Solà, J., Montero, J.I., Rieradevall, J., 2015b. An environmental and economic life cycle assessment of Rooftop Greenhouse (RTG) implementation in Barcelona, Spain. Assessing new forms of urban agriculture from the greenhouse structure to the final product level. Int. J. Life Cycle Assess. doi:10.1007/s11367-014-0836-9

Sanyé-Mengual, E., Orsini, F., Oliver-Solà, J., Rieradevall, J., Montero, J., Gianquinto, G., 2015c. Techniques and crops for efficient rooftop gardens in Bologna, Italy. Agron. Sustain. Dev. 35, 1477-1488. doi:10.1007/s13593-015-0331-0

Satterthwaite, D., 2008. Cities' contribution to global warming: notes on the allocation of greenhouse gas emissions. Environ. Urban. 20, 539-549. doi:10.1177/0956247808096127

Scheuer, C., Keoleian, G.A., Reppe, P., 2003. Life cycle energy and environmental performance of a new university building: modeling challenges and design implications. Energy Build. 35, 1049-1064. doi:10.1016/S0378-7788(03)00066-5

Sevigné-Itoiz, E., Gasol, C.M., Rieradevall, J., Gabarrell, X., 2015. Methodology of supporting decisionmaking of waste management with material flow analysis (MFA) and consequential life cycle assessment (CLCA): Case study of waste paper recycling. J. Clean. Prod. 105, 253-262. doi:10.1016/j.jclepro.2014.07.026

Sevigné-Itoiz, E., Gasol, C.M., Rieradevall, J., Gabarrell, X., 2014. Environmental consequences of recycling aluminum old scrap in a global market. Resour. Conserv. Recycl. 89, 94-103. doi:10.1016/j.resconrec.2014.05.002

Sevigné Itoiz, E., Gasol, C.M., Farreny, R., Rieradevall, J., Gabarrell, X., 2013. CO2ZW: Carbon footprint tool for municipal solid waste management for policy options in Europe. Inventory of Mediterranean countries. Energy Policy 56, 623-632. doi:10.1016/j.enpol.2013.01.027

Sierra-Pérez, J., Boschmonart-Rives, J., Dias, A.C., Gabarrell, X., 2016a. Environmental implications of the use of agglomerated cork as thermal insulation in buildings. J. Clean. Prod. doi:10.1016/j.jclepro.2016.02.146

Sierra-Pérez, J., Boschmonart-Rives, J., Gabarrell, X., 2016b. Environmental assessment of façadebuilding systems and thermal insulation materials for different climatic conditions. J. Clean. Prod. 113, 102-113. doi:10.1016/j.jclepro.2015.11.090

Slagstad, H., Brattebø, H., 2012. LCA for household waste management when planning a new urban settlement. Waste Manag. 32, 1482-1490. doi:10.1016/j.wasman.2012.03.018

Song, Q., Wang, Z., Li, J., 2013. Environmental performance of municipal solid waste strategies based on LCA method: A case study of Macau. J. Clean. Prod. 57, 92-100. doi:10.1016/j.jclepro.2013.04.042

Stokes, J.R., Horvath, A., 2009. Energy and air emission effects of water supply. Environ. Sci. Technol. 43, 2680-2687. doi:10.1021/es801802h

Strohbach, M.W., Arnold, E., Haase, D., 2012. The carbon footprint of urban green space-A life cycle approach. Landsc. Urban Plan. 104, 220-229. doi:10.1016/j.landurbplan.2011.10.013

Sugar, L., Kennedy, C., Leman, E., 2012. Greenhouse Gas Emissions from Chinese Cities. J. Ind. Ecol. 
16, 552-563. doi:10.1111/j.1530-9290.2012.00481.x

Sustainable Cities Institute. National League of Cities, 2013. Topics [WWW Document]. URL http://www.sustainablecitiesinstitute.org/topics

Syrrakou, E., Papaefthimiou, S., Yianoulis, P., 2006. Eco-efficiency evaluation of a smart window prototype. Sci. Total Environ. 359, 267-82. doi:10.1016/j.scitotenv.2005.10.023

Tähkämö, L., Ylinen, A., Puolakka, M., Halonen, L., 2012. Life cycle cost analysis of three renewed street lighting installations in Finland. Int. J. Life Cycle Assess. 17, 154-164. doi:10.1007/s11367011-0345-Z

Tarnacki, K., Meneses, M., Melin, T., van Medevoort, J., Jansen, A., 2012. Environmental assessment of desalination processes: Reverse osmosis and Memstill@. Desalination 296, 69-80. doi:10.1016/j.desal.2012.04.009

Thomas, B., McDougall, F., 2005. International expert group on life cycle assessment for integrated waste management. J. Clean. Prod. 13, 321-326. doi:10.1016/j.jclepro.2004.02.021

Thormark, C., 2002. A low energy building in a life cycle-its embodied energy, energy need for operation and recycling potential. Build. Environ. 37, 429-435. doi:10.1016/S0360-1323(01)000336

UN-HABITAT, 2014. The Future We Want. The City We Need. http://unhabitat.org/the-future-we-wantthe-city-we-need/.

UN-HABITAT, 2012. World Urban Campaign. https://issuu.com/worldurbancampaign/docs/wuc-2015brochure-web? $=22673641 / 32133275$ [WWW Document]. URL https://issuu.com/worldurbancampaign/docs/wuc-2015-brochure-web?e=22673641/32133275

UN-HABITAT, 2011. Hot Cities: Battle-ground for climate change. Global Report on Human Settlement 2011. [WWW Document]. URL http://mirror.unhabitat.org/downloads/docs/E_Hot_Cities.pdf (accessed 5.7.16).

UN-HABITAT, 2010. Planning Sustainable Cities: UN-HABITAT Practices and Perspectives. http://unhabitat.org/planning-sustainable-cities-un-habitat-practices-and-perspectives/. Kenya.

UN. United Nations, 2013. World Economic and Social Survey 2013. Chapter III Towards sustainable cities. http://www.un.org/en/development/desa/policy/wess/wess_current/wess2013/Chapter3.pdf.

UN. United Nations. Department of Economic and Social Affairs. Population Division, 2012. World Urbanization Prospects: The 2011 Revision, CD-ROM Edition.

UNCSD Secretariat, 2012. Sustainable Cities. RIO 2012 Issues Briefs. United Nations Conference on Sustainable Development. http://www.uncsd2012.org/content/documents/217Issues Brief No 5 Sustainable Cities FINAL.pdf.

UNEP-SETAC, 2011. Towards a Life Cycle Sustainability Assessment: Making Informed Choices on Products. UNEP-SETAC Life-Cycle Initiative, Paris, France.

UNEP-SETAC, 2009. Guidelines for Social Life Cycle Assessment of Products, Management. UNEPSETAC Life Cycle Initiative, Bourdeaux.

UNEP-SETAC Life Cycle Initiative, 2017. What is Life Cycle Thinking? http://www.lifecycleinitiative.org/starting-life-cycle-thinking/what-is-life-cycle-thinking/ [WWW Document]. 
UNEP. United Nations Environment Programme, 2012. Sustainable, Resource Efficient Cities - Making it Happen! http://www.unep.org/urban_environment/PDFs/SustainableResourceEfficientCities.pdf.

UNEP. United Nations Environment Programme, 2011. Cities. Investing in energy and resource efficiency. http://www.unep.org/greeneconomy/Portals/88/documents/ger/GER_12_Cities.pdf.

UNEP. United Nations Environment Programme, 2009. Methodology for the preparation of GEO Cities Reports. Training Manual Version 3.

http://www.pnuma.org/deat1/pdf/Metho_GEOCitiesinddOK.pdf.

Vandevyvere, H., Stremke, S., 2012. Urban planning for a renewable energy future: Methodological challenges and opportunities from a design perspective. Sustainability 4, 1309-1328. doi:10.3390/su4061309

Vargas-Parra, M.V., Rovira, M.R., Gabarrell, X., Villalba, G., 2014. Cost effective rainwater harvesting system in the Metropolitan area of Barcelona. J. Water Supply Res. Technol. - AQUA.

Venkatesh, G., Hammervold, J., Brattebø, H., 2009. Combined MFA-LCA for Analysis of Wastewater Pipeline Networks. J. Ind. Ecol. 13, 532-550. doi:10.1111/j.1530-9290.2009.00143.x

Vergara, S.E., Damgaard, A., Horvath, A., 2011. Boundaries matter: Greenhouse gas emission reductions from alternative waste treatment strategies for California's municipal solid waste. Resour. Conserv. Recycl. 57, 87-97. doi:10.1016/j.resconrec.2011.09.011

Vince, F., Aoustin, E., Bréant, P., Marechal, F., 2008. LCA tool for the environmental evaluation of potable water production. Desalination 220, 37-56. doi:10.1016/j.desal.2007.01.021

Vinyes, E., Oliver-Solà, J., Ugaya, C., Rieradevall, J., Gasol, C.M., 2012. Application of LCSA to used cooking oil waste management. Int. J. Life Cycle Assess. 18, 445-455. doi:10.1007/s11367-0120482-z

Wong, N.H., Tay, S.F., Wong, R., Ong, C.L., Sia, A., 2003. Life cycle cost analysis of rooftop gardens in Singapore. Build. Environ. 38, 499-509. doi:10.1016/S0360-1323(02)00131-2

Zabalza Bribián, I., Valero Capilla, A., Aranda Usón, A., 2011. Life cycle assessment of building materials: Comparative analysis of energy and environmental impacts and evaluation of the ecoefficiency improvement potential. Build. Environ. 46, 1133-1140. doi:10.1016/j.buildenv.2010.12.002

Zamorano, M., Molero, E., Grindlay, a., Rodríguez, M.L., Hurtado, a., Calvo, F.J., 2009. A planning scenario for the application of geographical information systems in municipal waste collection: A case of Churriana de la Vega (Granada, Spain). Resour. Conserv. Recycl. 54, 123-133. doi:10.1016/j.resconrec.2009.07.001

Zhao, M., Kong, Z. hong, Escobedo, F.J., Gao, J., 2010. Impacts of urban forests on offsetting carbon emissions from industrial energy use in Hangzhou, China. J. Environ. Manage. 91, 807-813. doi:10.1016/j.jenvman.2009.10.010 

Tables

Table 1. Identification of strategies towards urban sustainability

\begin{tabular}{|c|c|c|c|c|c|c|c|c|c|c|c|c|c|c|c|c|c|}
\hline \multirow{2}{*}{ Issue } & \multirow{2}{*}{ Strategy } & \multirow{2}{*}{ ID } & \multicolumn{15}{|c|}{ Literature } \\
\hline & & & 1 & 2 & 3 & 4 & 5 & 6 & 7 & 8 & 9 & 10 & 11 & 121 & 13 & 14 & 15 \\
\hline \multirow{4}{*}{ Buildings } & $\begin{array}{l}\text { Enhance the efficient use of energy, water } \\
\text { and other resources }\end{array}$ & $\mathrm{B} 1$ & $x$ & & $x$ & $\times$ & $x$ & $\times$ & & $\times$ & & & $\times$ & & & $\times$ & \\
\hline & Support the generation of renewable energy & $\mathrm{B} 2$ & & & & & & & & $x$ & & & $x$ & & & & \\
\hline & $\begin{array}{l}\text { Promote the use of efficient and sustainable } \\
\text { materials }\end{array}$ & B3 & & & & $\times$ & & & & $\times$ & & & $\times$ & & & $\times$ & \\
\hline & $\begin{array}{l}\text { Enhance reuse and recycling alternative for } \\
\text { an increased durability }\end{array}$ & B4 & $x$ & & & & & & & & & & & & & & \\
\hline \multirow{4}{*}{ Energy } & $\begin{array}{l}\text { Support the transition towards the use of } \\
\text { renewable energy sources }\end{array}$ & E1 & $x$ & $\times$ & & $\times$ & $\times$ & $\times$ & & $\times$ & $\times$ & & $\times$ & & $x$ & & \\
\hline & Promote the self-supply of energy & E2 & & & & & & $x$ & & $x$ & & & & & & & \\
\hline & Improve energy efficiency & E3 & $x$ & $x$ & $x$ & $\times$ & $x$ & $x$ & & $x$ & $x$ & & $\times$ & & $x$ & $\times$ & \\
\hline & $\begin{array}{l}\text { Ensure the access to affordable energy } \\
\text { resources to the population }\end{array}$ & $\mathrm{E} 4$ & & & $x$ & & $x$ & $\times$ & & $\times$ & $x$ & $\times$ & & & & & \\
\hline \multirow[b]{2}{*}{ Food } & Build up urban agriculture & F1 & & $x$ & & & $x$ & $x$ & & $x$ & & & $x$ & & & & \\
\hline & $\begin{array}{l}\text { Promote regional and local food products } \\
\text { (e.g., farmer's markets) }\end{array}$ & $\mathrm{F} 2$ & $\times$ & & & & $x$ & $\times$ & & $\times$ & & $x$ & $\times$ & & & & \\
\hline \multirow{2}{*}{$\begin{array}{c}\text { Green } \\
\text { spaces and } \\
\text { landscape }\end{array}$} & Increase green areas in cities & G1 & & $x$ & & $\times$ & $x$ & $\times$ & $x$ & $\times$ & $x$ & $x$ & $x$ & & & & \\
\hline & $\begin{array}{l}\text { Foster green buildings (e.g., green roofs, } \\
\text { green façades, living walls) }\end{array}$ & $\mathrm{G} 2$ & & & $x$ & & $x$ & $\times$ & & $\times$ & & $x$ & & & & & \\
\hline \multirow{5}{*}{ Mobility } & $\begin{array}{l}\text { Reduce private car use and promote } \\
\text { alternative means of transportation }\end{array}$ & M1 & $\times$ & $\times$ & $x$ & & $x$ & & & & $\times$ & $x$ & $\times$ & & & & $x$ \\
\hline & $\begin{array}{l}\text { Promote efficient and fossil fuel-free } \\
\text { private vehicles }\end{array}$ & M2 & $\times$ & & $x$ & & $x$ & & & & & $\times$ & $\times$ & & & & \\
\hline & $\begin{array}{l}\text { Promote efficient and fossil fuel-free } \\
\text { vehicles for public transportation }\end{array}$ & M3 & $\times$ & & $x$ & & $x$ & & & & & $\times$ & $\times$ & & & & $x$ \\
\hline & $\begin{array}{l}\text { Reduce and optimize heavy trucks } \\
\text { circulation in urban areas }\end{array}$ & M4 & $\times$ & & $x$ & & & & & & & & $\times$ & & & & \\
\hline & $\begin{array}{l}\text { Increase the use of Intelligent Transport } \\
\text { Systems (ITS) }\end{array}$ & M5 & & & $x$ & & & & & & & $\times$ & $\times$ & & & & \\
\hline \multirow{4}{*}{$\begin{array}{l}\text { Urban } \\
\text { Planning }\end{array}$} & $\begin{array}{l}\text { Promote the integration of land use and } \\
\text { transportation in decision-making }\end{array}$ & UP1 & & & & & & & $\times$ & & $x$ & & & & & & \\
\hline & $\begin{array}{l}\text { Promote a compact urban model as an } \\
\text { opposition to sprawl }\end{array}$ & UP2 & & & & $\times$ & & & & & $x$ & & & & & & \\
\hline & Promote regional planning & UP3 & & & & & & & $x$ & & $x$ & & & & & & \\
\hline & Promote sustainable urbanism & UP4 & & & & & & & $x$ & & & $\times$ & & & & & \\
\hline \multirow[t]{2}{*}{ Waste } & $\begin{array}{l}\text { Improve the efficiency of collection and } \\
\text { waste management systems }\end{array}$ & W1 & $\times$ & & & $\times$ & & $\times$ & & & & & & & & & \\
\hline & Promote waste prevention & W2 & $x$ & $x$ & & $\times$ & & $x$ & & & & & & & & & \\
\hline \multirow{5}{*}{ Water } & $\begin{array}{l}\text { Promote efficient water and sewer } \\
\text { networks in urban planning }\end{array}$ & Wa1 & & $x$ & $x$ & & $x$ & $x$ & $x$ & $x$ & $x$ & $\times$ & $x$ & $x$ & & & $x$ \\
\hline & $\begin{array}{l}\text { Implement retrofit systems (e.g., } \\
\text { desalination and water recycling) }\end{array}$ & Wa2 & & & $x$ & & $x$ & $x$ & $x$ & & & & $x$ & $x$ & & & $x$ \\
\hline & $\begin{array}{l}\text { Integrate bio-infiltration and natural } \\
\text { retention processes in urban areas }\end{array}$ & Wa3 & & $x$ & & & & & $x$ & $x$ & $x$ & & $x$ & & & & \\
\hline & $\begin{array}{l}\text { Implement rainwater harvesting systems } \\
\text { (RWHS) }\end{array}$ & Wa4 & & $x$ & & & & $x$ & & $\times$ & $x$ & & $\times$ & $x$ & & & \\
\hline & $\begin{array}{l}\text { Promote efficient waste- and greywater } \\
\text { treatment and recycling alternatives }\end{array}$ & Wa5 & & $\times$ & $x$ & & $x$ & $x$ & $x$ & $x$ & $x$ & & $x$ & $x$ & & & \\
\hline
\end{tabular}

1- (European Commission, 2016a); 2- (UNEP 2011); 3- (UNCSD Secretariat, 2012); 4- (UN 2013); 5- (UNEP 2012); 6- (UNEP 2009); 7- (Sustainable Cities Institute 2013); 8- (UN-HABITAT, 2010); 9- (European Commission, 2010b); 10- (Nethersole et al., 2012); 11- (IDAE 2012); 12- (European Commission, 2016b); 13- (EIP-SCC 2016); 14- (UN-HABITAT, 2012); 15- (UNHABITAT, 2014) 
Table 2. Literature search: Common keywords, specific keywords, number of papers reviewed and relevance by issue

\begin{tabular}{|c|c|c|c|c|}
\hline Issue & Common keywords & Specific keywords & \# papers & Relevance \\
\hline Buildings & \multirow{8}{*}{$\begin{array}{l}\text { Life cycle assessment, } \\
\text { Life cycle costing, } \\
\text { Social LCA, } \\
\text { Sustainability assessment, } \\
\text { Sustainable cities, } \\
\text { Urban sustainability, } \\
\text { Carbon footprint, } \\
\text { Water footprint, } \\
\text { Environmental } \\
\text { performance }\end{array}$} & $\begin{array}{l}\text { Sustainable construction, building energy, } \\
\text { renewable energy, renewable material, } \\
\text { insulation materials, embodied energy, } \\
\text { energy saving, zero energy building, low } \\
\text { energy building }\end{array}$ & $24(*)$ & $17 \%(*)$ \\
\hline Energy & & $\begin{array}{l}\text { Energy city, urban energy generation, } \\
\text { renewable energy, sustainable energy } \\
\text { technologies }\end{array}$ & 6 & $4 \%$ \\
\hline Food & & $\begin{array}{l}\text { Urban agriculture, urban garden, allotment, } \\
\text { rooftop garden, urban food, local food, } \\
\text { periurban agriculture, urban farming, urban } \\
\text { gardening }\end{array}$ & 15 & $10 \%$ \\
\hline $\begin{array}{l}\text { Green spaces } \\
\text { and landscape }\end{array}$ & & $\begin{array}{l}\text { Park, green spaces, green area, urban park, } \\
\text { urban forestry, urban green, urban } \\
\text { landscape }\end{array}$ & 15 & $10 \%$ \\
\hline Mobility & & \begin{tabular}{|l} 
Electric mobility, electric vehicles \\
infrastructure, hydrogen vehicles, low \\
carbon transport, ITS (Intelligent Transport \\
Systems), efficient transport systems, \\
sustainable public transport, public \\
transport
\end{tabular} & 9 & $7 \%$ \\
\hline Urban planning & & $\begin{array}{l}\text { Urban planning, city planning, urban } \\
\text { design, urban development, environmental } \\
\text { planning, city development, urban sprawl, } \\
\text { urban zoning }\end{array}$ & 6 & $4 \%$ \\
\hline Waste & & $\begin{array}{l}\text { Waste treatment, municipal solid waste, } \\
\text { selective collection systems, integrated } \\
\text { waste management, waste recycling, } \\
\text { incineration, landfilling, energy recovery }\end{array}$ & 26 & $14 \%$ \\
\hline Water & & $\begin{array}{l}\text { Water, wastewater, sanitation, drainage, } \\
\text { rainwater harvesting, best management } \\
\text { practices, graywater, wastewater recycling, } \\
\text { sewer, supply, hydrology, green and gray } \\
\text { infrastructure, conventional treatment, } \\
\text { alternative water supply }\end{array}$ & 50 & $34 \%$ \\
\hline
\end{tabular}

(*) In this study, only the most relevant papers were considered due to the large amount of literature on LCA and buildings

Table 3. Number of studies, coverage of sustainability dimensions, type of study and indicators use by urban issue. Note that the number of studies does not add up to the total in each group because some of them combine multiple options

\begin{tabular}{lcccccccccc}
\hline & & \multicolumn{2}{c}{ Type of study } & \multicolumn{3}{c}{ Sustainability dimensions } & \multicolumn{2}{c}{ LCA indicators used } \\
\cline { 2 - 11 } Issue & $\#$ & $\begin{array}{c}\text { Life } \\
\text { cycle } \\
\text { tools }\end{array}$ & $\begin{array}{c}\text { Integrated } \\
\text { schemes }\end{array}$ & LCA & LCC & S-LCA & LCSA & $\begin{array}{c}\text { Only } \\
\text { GW }\end{array}$ & $\begin{array}{c}\text { Only } \\
\text { GW \& } \\
\text { Energy }\end{array}$ & Complete \\
\hline Buildings & $24^{*}$ & 21 & 3 & 21 & 3 & 0 & 0 & 3 & 3 & 17 \\
\hline Energy & 6 & 4 & 2 & 4 & 2 & 0 & 0 & 2 & 0 & 2 \\
\hline Food & 15 & 13 & 1 & 15 & 3 & 0 & 0 & 3 & 5 & 7 \\
\hline Green spaces & 15 & 14 & 1 & 9 & 5 & 1 & 0 & 1 & 0 & 8 \\
\hline Mobility & 9 & 8 & 1 & 8 & 2 & 0 & 1 & 1 & 3 & 4 \\
\hline Urban planning & 6 & 2 & 4 & 6 & 0 & 0 & 0 & 2 & 1 & 2 \\
\hline Waste & 26 & 24 & 2 & 24 & 2 & 1 & 1 & 3 & 2 & 21 \\
\hline Water & 50 & 38 & 12 & 42 & $18 * *$ & 0 & 0 & 8 & 8 & 30 \\
\hline
\end{tabular}

(*) In this study, only the most relevant papers were considered due to the large amount of literature on LCA and buildings; (**) Included those EIO-LCA that also accounted for costs 


\section{Figures}

Figure 1. City boundaries considered in the analysis, including urban and periurban areas, and background processes.

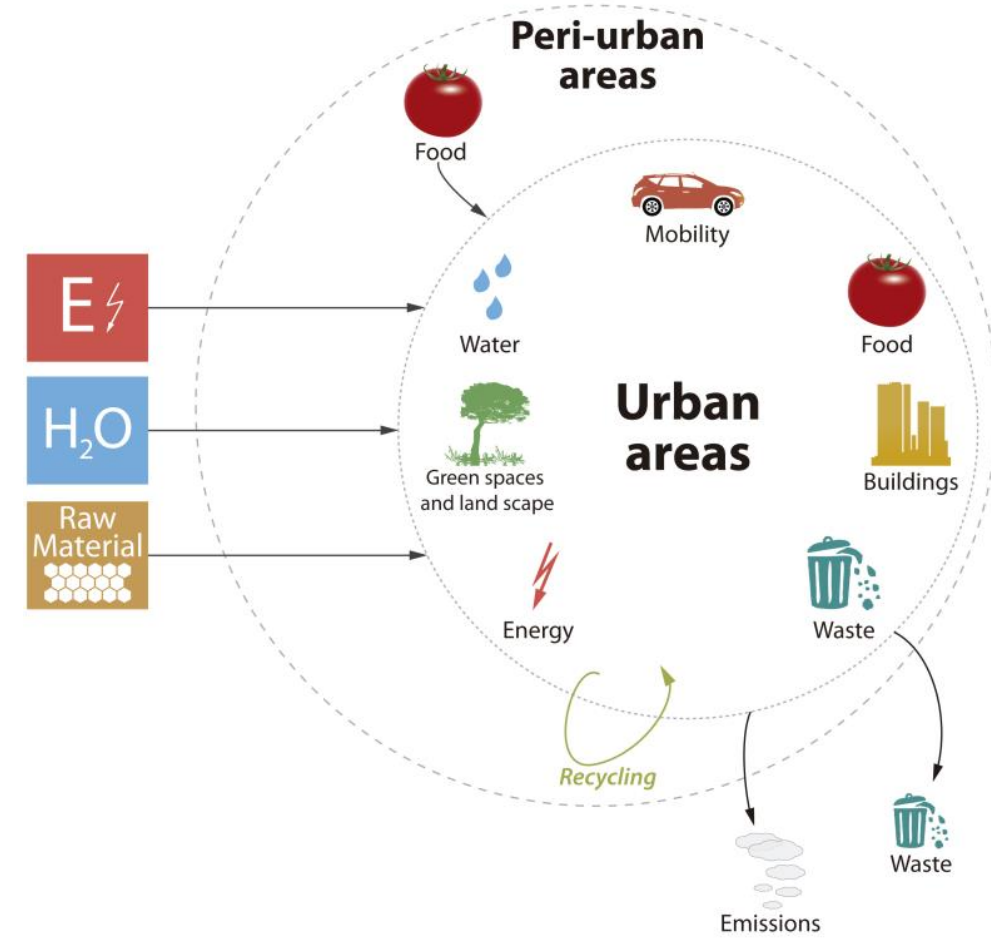

Figure 2. Interrelations among urban issues towards sustainability and presence in life cycle studies. The bubbles depict the overlaps among two or more urban issues and an example for each overlap is provided.

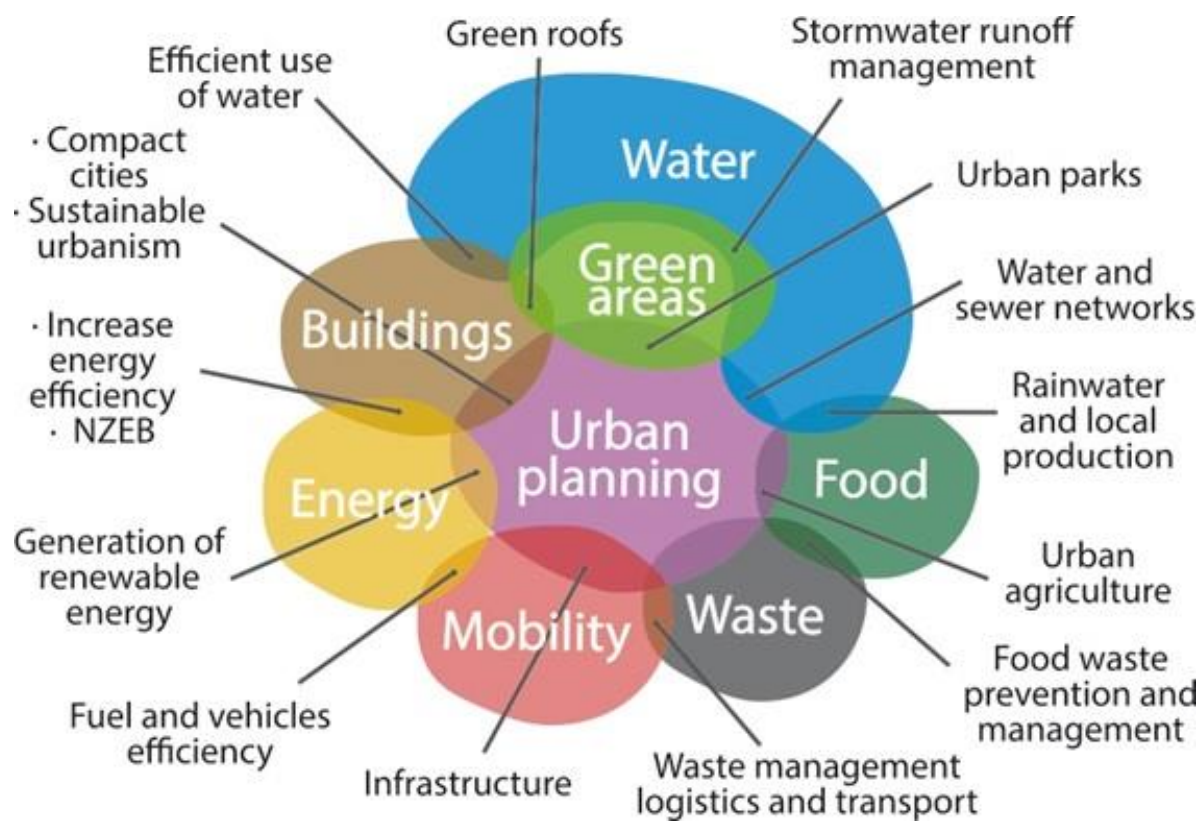

